\title{
NcoI RESTRICTION FRAGMENT LENGTH POLYMORPHISM AT - 308 OF THE TUMOR NECROSIS FACTOR ALPHA (TNFA) PROMOTER REGION IN KOREAN
}

\author{
Kyoung Sook PARK, ${ }^{1, *}$ Min-Young KIM, ${ }^{2}$ and Jee-Won MoK ${ }^{1}$ \\ ${ }^{1}$ Department of Biology, SungShin Women's University, Seoul 136-742, Korea \\ ${ }^{2}$ Hanhyo Institutes of Technology, Shiheung 429-010, Korea
}

Summary Tumor necrosis factor alpha $(T N F A)$ is a cytokine, which is secreted from activated macrophage, with a broad range of biological activities. The gene encoding TNFA is located in tandem with the TNFB gene within the HLA complex on chromosome 6p21.3. We detected a single base polymorphism in the human TNFA gene promoter region in 300 unrelated Korean individuals. The TNFA promoter region which showed a $G$ to A transition at position of -308 was investigated by $N c o I$ restriction fragment length polymorphism analysis. A biallelic polymorphism of TNFA gene showed fragments of $87 / 20 \mathrm{bp}$ and $107 \mathrm{bp}$ acting as $T N F A^{*} l$ allele and $T N F A^{*} 2$ allele, respectively. The allele frequencies of $T N F A^{*} 1$ and $T N F A^{*} 2$ were 0.8783 and 0.1217 , respectively. The $21.7 \%$ of heterozygosity was observed. No association between promoter region phenotypes of TNFA and the first intron phenotypes of TNFB was observed in Korean. Allele frequencies of Koreans were compared with that of Europeans.

Key Words TNFA, NcoI-RFLP, Korean

\section{Introduction}

The gene encoding tumor necrosis factor alpha (TNFA) is located in tandem with the tumor necrosis factor beta (TNFB) gene between $H L A-B$ and $C 2$ gene within the MHC region on chromosome 6p21.3. (Spies et al., 1986; Carroll et al., 1987; Ziegler et al., 1991). The primary transcript of human TNF- $\alpha$ consists of 2,762 bp which has four exons and three introns (Nedwin et al., 1985; Nedospasov et al., 1986). TNF- $\alpha$ and TNF- $\beta$, which have similar biological activities, share approximately $30 \%$ amino acid homology (Goeddel et al., 1986).

Received September 13, 1996; Revised version accepted November 14, 1996.

* To whom correspondence should be addressed. 
TNF- $\alpha$ is a cytokine with tumoricidal and tumorstatic properties and an endogenous mediator of inflammatory functions in vivo, although the mechanism is not fully understood. The major sources of TNF- $\alpha$ are the activated macrophage, monocyte, and several other cell types (Sariban et al., 1988; Aggarwal, 1992).

The DNA sequences of TNFA gene can vary in a normal population whether or not they code for a protein. Moreover, the DNA sequences determine a phenotype. A polymorphism in TNFA gene is determined not only by direct sequencing (Messer et al., 1991) but also by other methods: i.e., polymerase chain reaction NcoI restriction fragment length polymorphism (PCR-NcoI-RFLP) typing (Wilson et al., 1992), polymerase chain reaction single strand conformational polymorphism typing (PCR-SSCP) (Wilson et al., 1993), and polymerase chain reaction allele specific oligonucleotide typing (PCR-ASO) (D'Alfonso and Richiardi, 1994). We applied the PCR-NcoI-RFLP method to screen polymorphic variations at position -308 of the TNFA promoter in unrelated Korean individuals. Furthermore, the association between promoter region phenotypes of TNFA and the first intron phenotypes of $T N F B$ was examined.

\section{Materials and Methods}

The subjects in the sample were comprised of 300 unrelated Koreans. Genomic DNA was prepared from peripheral blood by proteinase K (BoehringerMannheim) and phenol-chloroform extraction. Extracted genomic DNA $(0.2 \mu \mathrm{g})$ was amplified by the polymerase chain reaction with 1 unit of the Taq DNA polymerase (Poscochem R\&D Center) and $20 \mathrm{nmol}$ of each primer in a Perkin/ Elmer Cetus 9600. For TNFA, following primers were used: 5'AGGCAATAGGTTTTGAGGGCCAT3' (TNFA1), and 5'TCCTCCCTGCTCCGATTCCG3' (TNFA2) which were hybridized to positions of -332 to -310 and of -245 to -226 of the TNFA gene (Fig. 1) (Wilson et al., 1992).

Reaction conditions contained $200 \mu \mathrm{M}$ of dNTPs (Boehringer-Mannheim),

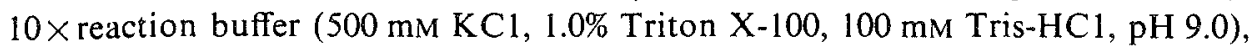
$15 \mathrm{mM} \mathrm{MgCl}{ }_{2}$. Cycling was performed at $94^{\circ} \mathrm{C}$ for $4 \mathrm{~min}, 58^{\circ} \mathrm{C}$ for $20 \mathrm{sec}$, and $72^{\circ} \mathrm{C}$ for $35 \mathrm{sec}$ followed by 35 cycles of $94^{\circ} \mathrm{C}$ for $30 \mathrm{sec}, 58^{\circ} \mathrm{C}$ for $20 \mathrm{sec}$, and $72^{\circ} \mathrm{C}$ for 35 sec with final cycle of $94^{\circ} \mathrm{C}$ for $30 \mathrm{sec}, 58^{\circ} \mathrm{C}$ for $20 \mathrm{sec}$, and $72^{\circ} \mathrm{C}$ for $4 \mathrm{~min}$. The expected PCR products were separated on 10\% polyacrylamide gel, stained with ethidium bromide $(\mathrm{EtBr})$ and visualized under UV light. Amplified product of $T N F A$ was digested with 1 unit of restriction enzyme, $N c o I$, for $12 \mathrm{hr}$ at $37^{\circ} \mathrm{C}$. To assign NCol digestion of amplified TNFA gene, cleaved DNA was analyzed by electrophoresis using $10 \%$ polyacrylamide gel and stained with $\mathrm{EtBr}$.

\section{Results and Discussion}

Three-hundred unrelated Korean subjects were screened for the polymorphism at -308 of TNFA promoter region. A 107 base pair sequence including the 


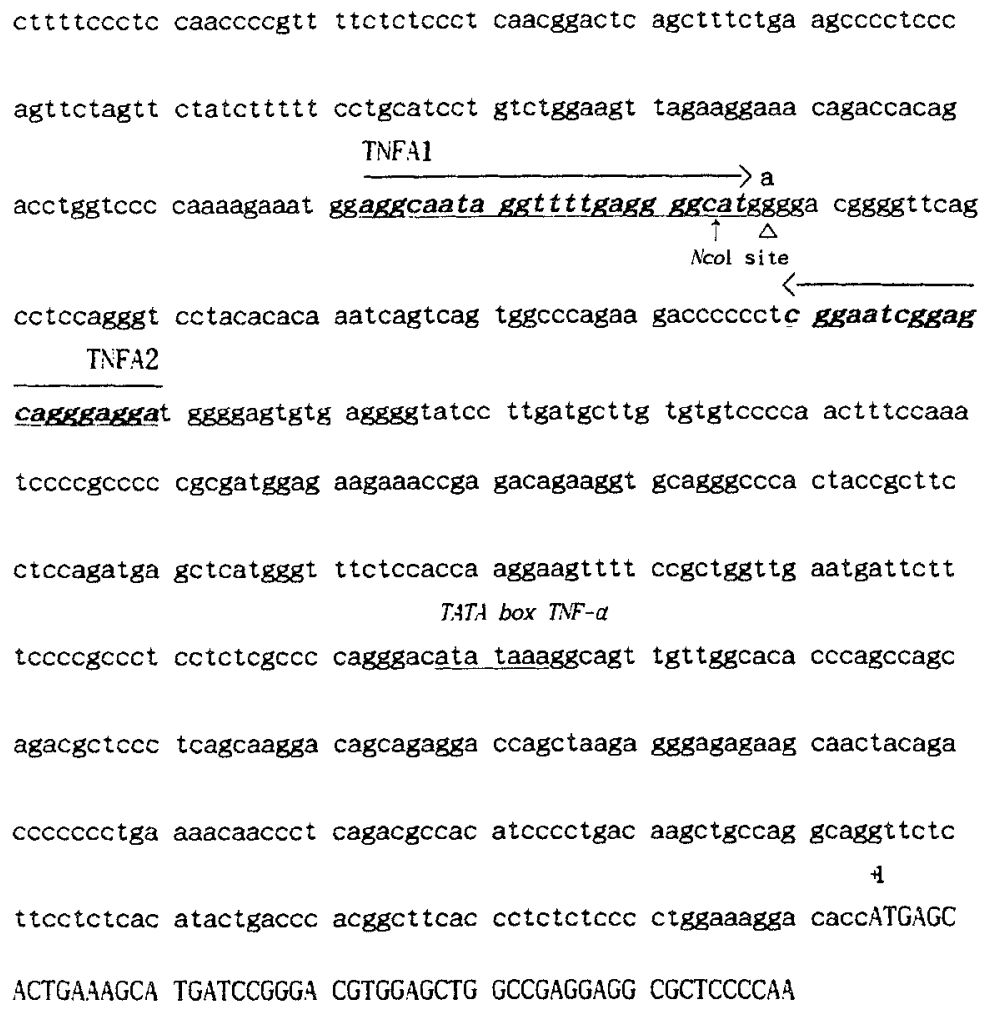

Fig. 1. Sequence of the $5^{\prime}$ promoter region of the TNFA gene (Nedospasov et al., 1986). The sequence is numbered in relation to the transcription start site $(+1)$. The TATA boxes are underlined and the arrowed lines are indicated as the two oligonucleotide primers for PCR amplification (from -332 to -226 ) (Wilson et al., 1992). The polymorphism at position -308 is indicated by a triangle. The capital letters are exon regions.

polymorphic site in TNFA promoter region, from position of -332 to -226 , was amplified and a polymorphism was observed in a $G$ vs $A$ transition at position -308 restriction site. Synthetic oligonucleotide primers were designed to recognize $N c o$ I by a single base change at the $3^{\prime}$ end of primer TNFAl and to yield the expected size fragment. While the $T N F A^{*} l$ allele corresponding to $N c o l$ fragment of $87 / 20 \mathrm{bp}$ showed the presence of CCATGG sequence, the TNFA*2 allele corresponding to $107 \mathrm{bp}$ fragment lacked $N c o I$ restriction site because of a point mutation of $\mathrm{G}$ sequence to A sequence (Fig. 2).

Using SSCP, the two alleles were clearly identified after partial denaturation of the PCR product at the same position of $-308 T N F A$ promoter region (Wilson et al., 1993, 1994). Wilson et al. (1992) showed that the mendelian segregation of this polymorphism was observed in 5 members of one family spanning two 


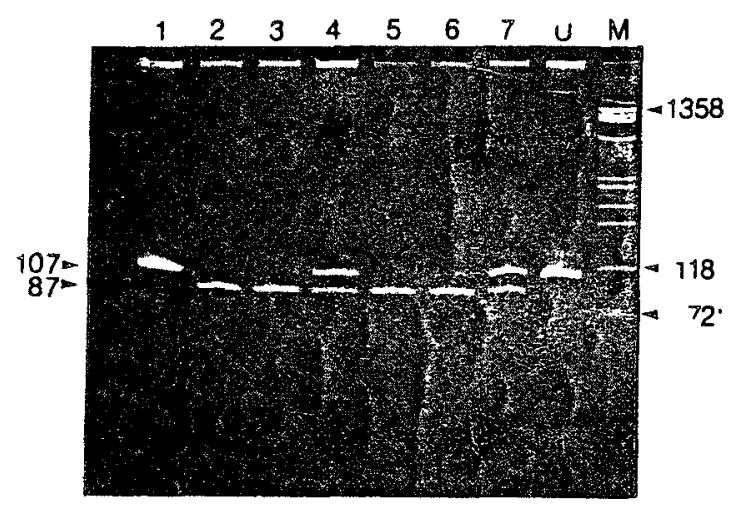

Fig. 2. Separation by $10 \%$ gel electrophoresis of the fragments obtained after PCR amplification of a $107 \mathrm{bp}$ segment of the TNFA gene digestion with $N \mathrm{CoI}$. $T N F A^{*} l(87+20 \mathrm{bp})$ and $T N F B^{*} 2(107 \mathrm{bp})$ fragments indicate NcoI site positive and negative. M: the size marker $\phi \mathrm{X174/HaelII;} \mathrm{U:} \mathrm{Ncol} \mathrm{untreated;}$ $T N F A^{*} 1 / T N F A^{*} 1:$ lanes 2, 3, 5, 6; TNFA ${ }^{*} l / T N F A^{*} 2:$ lanes 4, 7;TNFA*2/ $T N F A^{*}$ 2: lane 1 .

generations.

Recently the polymorphism of the human $T N F A$ promoter at different region was reported (Messer et al., 1991; D'Alfonso and Richiardi, 1994). The other biallelic polymorphism at position of -238 was observed including the substitution of guanine by adenosine using PCR-ASO (presence of A sequence $=T F N A-A$ allele, presence of $G$ sequence $=T N F A-G$ allele) typing. The gene frequencies of $T N F A-A$ and $T N F A-G$ were 0.93 and 0.07 , respectively (D'Alfonso and Richiardi, 1994). Messer and coworker (1991) showed a deletion of cytosine in TNFA promoter region ( -687 to -370 ) compared with other sequences by PCR-directed sequencing. But this position of TNFA promoter region did not reveal any polymorphic sequence variation.

In this study, the frequencies of TNFA genotypes at -308 position in $T N F A^{*}$ 1/TNFA* $1, T N F A^{*} 1 / T N F A^{*} 2$, and $T N F A^{*} 2 / T N F A^{*} 2$ were $77 \%(\mathrm{n}=231), 21.7 \%$ $(\mathrm{n}=65)$ and $1.3 \%(\mathrm{n}=4)$, respectively. The $21.7 \%$ of heterozygosity was observed. The allele frequencies of $T N F A^{*} 1$ and $T N F A^{*} 2$ were 0.8783 and 0.1217 , respectively. The test for Hardy-Weinberg equilibrium among random individuals showed no significant deviation from our expectations (Table 1).

The gene frequencies of TNFA in European and Korean populations are shown in Table 2. TNFA*1/TNFA*1 is common phenotype, and the TNFA*1 allele frequencies of Koreans are higher relative to that of the Europeans (Wilson et al., 1994; Cox et al., 1994; Brinkman et al., 1994).

It was suggested that $T N F A$ expression depends on polymorphic variations of TNFA promoter region itself or linkage association with HLA genotype (Molvig 
Table 1. Distribution of genotype at position -308 of the TNFA promoter region and allele frequencies by $\mathrm{NcoI}$ in Korean.

\begin{tabular}{lrrr}
\hline Genotype & Obs. (\%) & Exp. (\%) & Allele frequencies \pm SE \\
\hline$T N F A^{*} I / T N F A^{*} I$ & $231(77.0)$ & $231.4(77.1)$ & $T N F A^{*} 1=0.8783 \pm 0.0133$ \\
$T N F A^{*} I / T N F A^{*} 2$ & $65(21.7)$ & $64.2(21.4)$ & $T N F A^{*} 2=0.1217 \pm 0.0133$ \\
$T N F A^{*} 2 / T N F A^{*} 2$ & $4(1.3)$ & $4.4(1.5)$ & \\
\hline Total & $300(100.0)$ & $300.0(100.0)$ & \\
\hline$\chi^{2}=0.05$, d.f. $=1$. &
\end{tabular}

Table 2. Comparison of allele frequencies at position -308 of the $T N F A$ promoter region by $N$ col RFLP.

\begin{tabular}{lcccl}
\hline Population & $\mathrm{n}$ & $T N F A^{*} 1$ & $T N F^{*} 2$ & \multicolumn{1}{c}{ References } \\
\hline Korean & 300 & 0.88 & 0.12 & This study \\
European & 168 & 0.83 & 0.17 & Wilson et al., 1994 \\
England & 253 & 0.78 & 0.22 & Cox et al., 1994 \\
Netherlands & 88 & 0.76 & 0.24 & Brinkman et al., 1994 \\
\hline
\end{tabular}

Table 3. Association analysis between phenotypes at position - 308 of TNFA promoter region and the first intron region phenotypes of $T N F B$ in Korean.

\begin{tabular}{lrrrr}
\hline \multirow{2}{*}{ TNFA } & \multicolumn{4}{c}{ TNFB } \\
\cline { 2 - 5 } & \multicolumn{1}{c}{$1-1$} & \multicolumn{1}{c}{$1-2$} & \multicolumn{1}{c}{ Total } \\
\hline $1-1$ & $23(7.7 \%)$ & $103(34.3 \%)$ & $105(35.0 \%)$ & $231(77.0 \%)$ \\
$1-2$ & $3(1.0 \%)$ & $33(11.0 \%)$ & $29(9.7 \%)$ & $65(21.7 \%)$ \\
$2-2$ & $0(0.0 \%)$ & $1(0.3 \%)$ & $3(1.0 \%)$ & $4(1.3 \%)$ \\
Total & $26(8.7 \%)$ & $137(45.6 \%)$ & $137(45.7 \%)$ & $300(100.0 \%)$ \\
\hline
\end{tabular}

et al., 1988; Han et al., 1990, 1991; Wilson et al., 1993; D'Alfonso and Richiardi, 1994). Wilson et al. (1993) postulated that TNFA promoter region to be important in regulation of transcription and described a very strong association between the $T N F A^{*} 2$ allele and HLA Al, B8, DR3 and DQ2 haplotype. Furthermore, Wilson et al. (1994) investigated the significance of TNFA polymorphism in relation to autoimmune disorder where genetic factors play a role in susceptibility and autoantibody production. The frequency of the $T N F A^{*} 2$ allele increased in systemic lupus erythematosus compared with controls $(\mathrm{p}=0.04)$.

We previously studied an Ncol restriction site polymorphism in the first intron of the TNFB gene and examined an association between promoter region phenotypes of TNFA and the first intron phenotypes of TNFB was analyzed in 300 unrelated Korean individuals. We observed no association between TNFA and $T N F B$ alleles (Table 3), and this finding did not correspond to the results of Netherlands reported by Brinkman et al. (1994).

The polymorphism screened in this study was characterized in the TNFA gene of Korean population. 
Acknowledgments The present study was supported by a grant from the Korea Science and Engineering Foundation, KOSEF 95-0403-64-3.

\section{REFERENCES}

Aggarwal BB (1992): Comparative analysis of the structure and function of TNF- $\alpha$ and TNF- $\beta$. In: Aggarwal BB, Vilcek J (eds). Immunology Series 56. TNF. Vol. 56, Marcel Dekker, New York, pp 6l-78

Brinkman BMN, Giphart MJ, Verhoef A, Kaijzel EL, Naipal AMIH, Daha MR, Breedveld FC, Verweij CL (1994): Tumor necrosis factor $\alpha-308$ gene variants in relation to major histocompatibility complex alleles and felty's syndrome. Hum Immunol 41: 259-266

Carroll MC, Katzman P, Alicot EM, Koller BH, Geraghty DE, Orr HT, Strominger JL, Spies T (1987): Linkage map of the human major histocompatibility complex including the tumor necrosis factor genes. Proc Natl Acad Sci USA 84: 8535-8539

Cox A, Gonzalez AM, Wilson AG, Wilson RM, Ward JD, Artlett CM, Welsh K, Duff GW (1994): Comparative analysis of the genetic associations of HLA-DR3 and tumor necrosis factor alpha with human IDDM. Diabetologia 37: 500-503

D'Alfonso SD, Richiardi PM (1994): A polymorphism variation in a putative regulation box of the TNFA promoter region. Immunogenetics 39: $150-154$

Goeddel DV, Aggarwal BB, Gray PW, Leung DW, Nedwin GE, Palladino MA, Patton JS, Pennica D, Shiepard HM, Sugarman BJ, Wong GH (1986): Tumor necrosis factors: Gene structure and biological activities. Cold Spring Harbor Symp Quant Biol LI: 597-609

Han J, Brown T, Beutler B (1990): Endotoxin-responsive sequences control cachetin/tumor necrosis factor biosynthesis at the translational level. J Exp Med 171: $465-475$

Han J, Huez G, Beutler B (1991): Interactive effects of the tumor necrosis factor promoter and 3'-untranslated regions. J Immunol 146: 1843-1848

Messer G, Spengler U, Jung MC, Honold G, Blomer K, Pape GR, Riethmuller G, Weiss EH (1991): Polymorphic structure of the tumor necrosis factor (TNF) locus: an Nco I polymorphism in the first intron of the human TNF- $\beta$ gene correlates with a variant amino acid in position 26 and a reduced level of TNF- $\beta$ production. J Exp Med 173: 209-219

Molvig J, Baek L, Christensen P, Manogue KR, Vlassara H, Platz P, Nielsen LS, Svejgaard A, Nerup J (1988): Endotoxin-stimulated human monocyte secretion of interleukin 1, tumor necrosis factor alpha, and prostaglandin $E_{2}$ shows stable interindividual differences. Scand I Immunol 27: 705-716

Nedospasov SA, Shakhov AN, Turetskaya RL, Mett VA, Azizov MM, Georgiev GP, Korobko VG, Dobrynin VN, Filippov SA, Bystrov NS, Boldyreva EF, Chuvpilo SA, Chumakov AM, Shingarova LM, Ovchinnikov YA (1986): Tandem arrangement of genes coding for tumor necrosis factor $(\mathrm{TNF}-\alpha)$ and lymphotoxin $(\mathrm{TNF}-\beta)$ in the human genome. Cold Spring Harbor Symp Quant Biol L1: $611-624$

Nedwin GE, Naylor SL, Sakaguchi AY, Smith D, Jarret-Nedwin J, Pennica D, Goeddel DV, Gray PW (1985): Human lymphotoxin and tumor necrosis factor genes: structure, homology and chromosomal location. Nucleic Acids Res 13: 6361-6373

Sariban E, Imamura K, Luebbers R, Kufe D (1988): Transcriptional and posttranscriptional regulation of tumor necrosis factor gene expression in human monocytes. J Clin Invest 81: $1506-1510$

Spies T, Morton CC, Nedospasov SA, Fiers W, Poius D, Strominger JL (1986): Genes for the tumor necrosis factors $\alpha$ and $\beta$ are linked to the human major histocompatibility complex. Proc Natl Acad Sci USA 83: 8699-8702

Wilson AG, de Vries N, Pociot F, di Giovine FS, van der Putte LBA, Duff GW (1993): An allelic polymorphism within the human tumor necrosis factor $\alpha$ promoter region is strongly associated with HLA A1, B8, and DR 2 alleles. J Exp Med 177: 557-560

Wilson AG, di Giovine FS, Blakemore AIF, Duff GW (1992): Single base polymorphism in the

Jpn J Human Genet 
human tumor necrosis factor alpha (TNF $\alpha$ ) gene detectable by Nco I restriction of PCR product. Hum Mol Genet 1: 353

Wilson AG, Gordon C, di Giovine FS, de Vries N, van de Putte LBA, Emery P, Duff GW (1994): A genetic association between systemic lupus erythematosus and tumor necrosis factor alpha. Eur J Immunol 24: 191-195

Ziegler A, Field LL, Sakaguchi AY (1991): Report of the committee on the genetic constitution of chromosome 6. Cytogenet Cell Genet 58: 295-336

Vol. 42, No. 1, 1997 